\title{
Natural history of Ebstein's anomaly of tricuspid valve in childhood and adolescence \\ An international co-operative study of 505 cases
}

\author{
Hamish Watson \\ From the Department of Cardiology, University of Dundee
}

505 cases of Ebstein's anomaly have been collected from 61 centres in 28 countries: 258 were male and 247 were female. Thirty-five (infants) were less than I year old, 403 (children and adolescents) were between I and 25 years old, and 67 (adults) were over 25 years old. Of the infants, 72 per cent were in heart failure, but in 81 per cent of the others growth and development during infancy was said to have been average or good. Of the children and adolescents, 7 I per cent, and of the adults, 60 per cent, had little or no disability and were classified as cardiac grade I or II.

Catheterizations were carried out on 363 patients, with 13 deaths and 6 cardiac arrests: paroxysmal tachycardia occurred during the procedure in 90 of them. Necropsy was carried out in 93 cases: 48 per cent of those catheterized and 81 per cent of those coming to necropsy had associated congenital cardiac malformations. If defects in the interatrial septum are excluded the figures are 12 per cent and 42 per cent, respectively. The presence of an additional lesion appeared to increase the risk in those having surgical treatment.

Of the series, 10 per cent had ventricular pre-excitation and 28 per cent gave a history of paroxysmal dysrhythmia. Their presence was predictive for neither death nor dysrhythmia during cardiac catheterization, nor for sudden natural death.

Of the 505, 77 (13.3\%) died from natural causes, and 31 (54.4\%) of the 57 who had surgical treatment did not survive operation. Analysis of the surgical experience suggests that palliative procedures have little or nothing to offer and that replacement of the malformed tricuspid valve should be delayed, if possible, until the patient's heart is large enough to take an adult-size prosthesis or homograft.

This study was prompted, after it became apparent that replacement was likely to become the standard therapeutic remedy for severely damaged heart valves, by the clinical impression that many patients with Ebstein's anomaly of the tricuspid valve were relatively old, and that the mortality during childhood was relatively small. As the longterm prognosis of artificial valves was in doubt, and patients with Ebstein's anomaly were known to be bad surgical risks, it seemed important to determine whether or not it was necessary to replace the malformed tricuspid valve before they were old enough to receive a prosthesis that was large enough to have at least a chance of lasting a lifetime. Because the only way to establish the facts about such rare lesions is through fairly large scale international cooperation, the investigation was undertaken on Received 27 November 1973. behalf of the Association of European Paediatric Cardiologists with the help of the International Society of Cardiology, and was one of the joint research projects supported in part by the I.S.C. Scientific Council on Paediatric Cardiology. I am greatly indebted to those listed in the appendix who willingly contributed details of 520 patients from $6 \mathrm{I}$ centres in 28 countries spanning the world from North America to Australia, from which the 505 cases here reported were selected. The number of cases varied from $I$ to $6 I$, the average number was 8 , and 17 centres contributed a series of 10 or more cases.

\section{Methods}

The analysis was made from a questionnaire containing answers to 37 questions together with the electrocardiograms and $x$-rays of each case, which was then classified for diagnostic purposes by the writer as - (a) proved to 
the contributor's satisfaction by cardiac catheterization, angiocardiography, cardiac surgery, or necropsy, (b) probable from clinical features, $x$-rays, and electrocardiograms, (c) doubtful, or (d) unlikely. Only the 401 cases that were classified (a) and the ro4 cases classified (b) are included in the series. Ebstein-like malformations of the tricuspid valve in patients with pulmonary atresia and an intact interventricular septum were excluded, as were those occurring on the left side of the heart in bulboventricular inversion, the so-called corrected transposition.

For the purpose of this study, infancy is defined as the first year of life, and adolescence, using the Oxford English Dictionary's definition, extends to 25 years. After analysis of the surgical results, this span of 24 years, excluding the first year of life, was divided arbitrarily at 15 years because it seemed that most would be well enough grown by then to take an adult-size prosthetic tricuspid valve; it is freely admitted that many individuals might be large enough before this age, especially if they had a large heart with a widely dilated valve ring.

In an attempt to estimate the length of follow-up, the questions were framed to discover how long each patient had been observed since the diagnosis of Ebstein's anomaly had been made. It soon became obvious during the analysis that many had been observed since infancy or early childhood with a diagnosis of congenital heart disease though not yet recognized as having Ebstein's anomaly. All that can be said, therefore, is that some had been seen many times and most had been seen several times over a number of years; a few had been seen only once. This, then, is a retrospective view of the hospital population of patients with an uncommon life-threatening malformation that probably reflects the prevalence of the classical form of the anomaly in the community more accurately than it would for most other types of congenital cardiac malformation. It almost certainly underestimates the number of patients with Ebstein's anomaly who have small hearts and less severe tricuspid malformations, who are much more difficult to diagnose, especially as few of them have symptoms. The absence of many such cases from the series, however, tends to overestimate rather than underestimate the gravity of the prognosis for the remainder, because most of those with small hearts pass unrecognized and few of them die in childhood or adolescence: those who do die usually die sudden deaths from an unknown cause, and are often diagnosed at necropsy.

\section{Results}

\section{Sex and familial incidence}

Two hundred and fifty-eight of the 505 cases were male and 247 were female $(200 \mathrm{M}+20 \mathrm{I} F$ in (a); $58 \mathrm{M}+46 \mathrm{~F}$ in (b)), confirming that there is no difference between the sex incidence of this malformation (Vacca, Bussmann, and Mudd, 1958; Genton and Blount, 1967).

Two examples of familial incidence were reported:
Mexican sisters aged 5 and 7, both alive but with only a clinical diagnosis; and a brother and sister from Israel aged 20 and 12, both dead (the boy from heart failure, the girl following surgery) with necropsy proof of diagnosis.

\section{Associated congenital cardiac malformations}

Although the series contains a large number and variety of associated cardiac malformations, it is clear that the index of suspicion varied greatly in different centres. This applied not only to cases diagnosed clinically but also to those having intracardiac investigations; 6 clinics reported none, one of them with 13 catheterization reports. Only those noted in the 363 patients who had cardiac catheterization and in the 93 who had necropsy were analysed. Sixty cases were common to both groups.

Of those catheterized, $175(48 \%)$ were said to have associated lesions. That this underestimates their prevalence is suggested by the fact that no less than 8I per cent of the 93 cases examined after death were found to have other cardiac malformations. By far the commonest were defects in the interatrial septum. These were reported in 42 per cent of patients catheterized: 79 were classified as patent foramen ovale and 73 as atrial septal defects. The necropsy incidence was 60 per cent: 35 with patent foramen ovale and 23 with atrial septal defect. Only 2 primum defects were reported. In patients with Ebstein's anomaly communications between the atria are often a consequence of the haemodynamic upset caused by the malformed tricuspid valve and should probably not be counted as additional congenital malformations. If we exclude them, 12 per cent of the catheter series and 42 per cent of the necropsy series were still left with associated cardiac malformations. In the live group were 13 with ventricular septal defect, I9 with pulmonary stenosis, 3 with persistent ductus arteriosus, 2 with coarctation, and 8 with other malformations; 6 patients had a ventricular septal defect with pulmonary stenosis. At necropsy there were Io with ventricular septal defect, 9 with pulmonary stenosis, 19 with persistent ductus arteriosus, 2 with coarctation, and 14 with other malformations; 4 had ventricular septal defect with pulmonary stenosis. Other combinations, of which there were 22 and 25 in the catheter and necropsy groups respectively, nearly all included an atrial septal defect of one sort or another as one of the components. It is, of course, possible that the presence of associated cardiac malformations contributed to death in those coming to necropsy, but, even allowing for this, the number of additional lesions found during catheterization is considerable. 


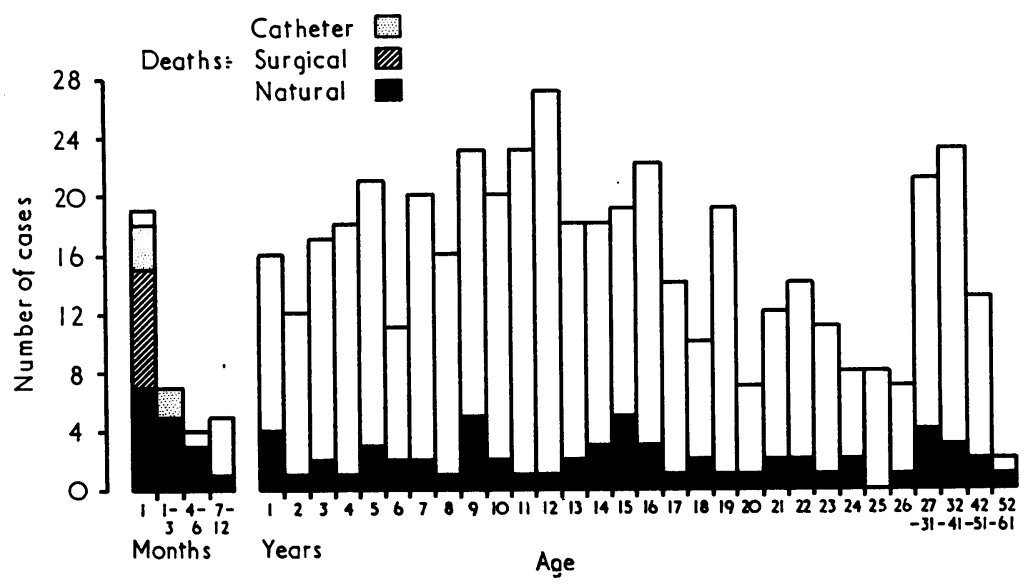

FIG. The numbers in the various age groups. The black areas represent all deaths from natural causes. The cross-hatched areas represent deaths during surgery and the stippled areas deaths during cardiac catheterization, in patients under I year of age only.

TABLE I The cardiac grade and sex of the 505 cases in the 3 age groups

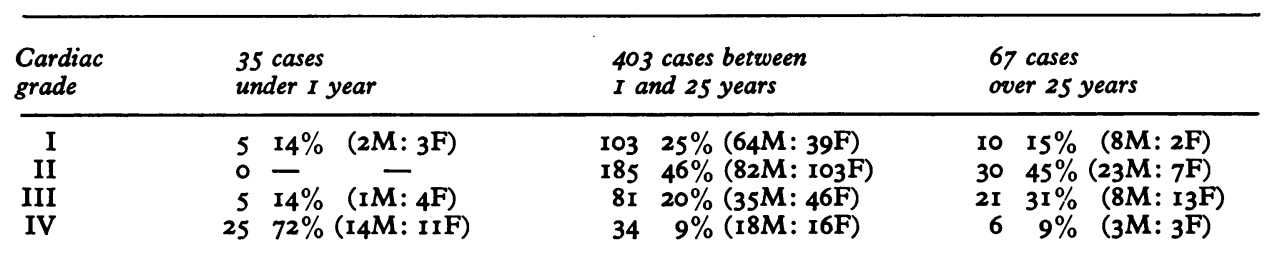

\section{Age and cardiac grade}

The numbers in the various age groups are shown in the Fig: the black areas indicate deaths from natural causes, which were not all primarily related to the cardiovascular system. In the years I to 25 , the average number of cases in each year is 16 , with a maximum of 27 and a minimum of 7 . The first year of life has been subdivided to show that after the first 6 months, prognosis in infancy improves rapidly to approximate that of childhood and adolescence. The cross-hatched areas represent those under I year of age who died after attempted palliative surgery, in most cases after an incorrect diagnosis, and the stippled areas those who did not survive cardiac catheterization. Those over 25 have been grouped because of their smaller number. This has no prognostic significance and would be expected in any survey of cases contributed by paediatric clinics. Those about whom details were available are included for comparison and came mostly from clinics seeing both children and adults.

The cardiac grade of the patient was assessed using the New York Heart Association's classification I, II, III, or IV and is shown in Table I, from which it can be seen that whereas 72 per cent of the infants were in heart failure, 71 per cent of the children and adolescents had little or no disability. Even 60 per cent of the adults, whose ages ranged from 26 to $6 \mathrm{I}$ years, were in cardiac grades I or II. If grades I and II, and III and IV are taken together there is little or no difference between the sexes except in those over 25, where men with little or no handicap outnumber women by three to one. The methods used in the survey make it impossible to say whether or not this has any significance.

The grade and sex of the 279 cases in the arbitrarily selected group between the ages of I and 15 years (Table 2) show no difference from the whole

TABLE 2 The cardiac grade and sex of the 279 cases between $I$ and 15 years of age

\begin{tabular}{lrll} 
Cardiac grade & \multicolumn{3}{c}{279 cases $I-15$ years } \\
\hline I & 72 & $26 \%$ & $(39 M: 33 F)$ \\
II & 130 & $47 \%$ & $(56 M: 74 F)$ \\
III & 52 & $18 \%$ & $(24 M: 28 F)$ \\
IV & 25 & $9 \%$ & $(11 M: 14 F)$ \\
\hline
\end{tabular}


group of I to 25 years; 73 per cent as opposed to $7 \mathrm{I}$ per cent being classified as in grade I or II. Grade II, of course, covers a fairly wide scatter of disability, depending as it does not only upon the doctor's assessment, but also upon the patient's or parents' opinion of what constitutes more than ordinary exertion. The bold will make light of their disability, the timid may exaggerate it, and many, having reset their sights in the light of what they have found they are able to do, have in fact redefined ordinary activity for themselves as something much less strenuous than would be acceptable to a healthy person. In this context too, those who have lived for many years with slight to moderate physical disability have often become so accustomed to it that they may no longer notice it; as, for example, those who strenuously deny symptoms yet feel so much better and more active after a successful mitral valvotomy. Though the quality of life for many of those classified as grade II is far from ideal, it is probably fair to say that they are not grossly disabled and that for the vast majority life is not at risk. Of the 288 patients between the ages of $I$ and 25 years in grades I and II, only 6 died sudden deaths (ages, 9, 9, I4, I6, I7, and 21 years) and only 3 died from congestive heart failure (ages 4,14 , and I5 years). They were all in grade II.

\section{Deaths and dysrythmias during cardiac cath- eterization}

Before considering the natural deaths in more detail, the iatrogenic deaths reported in the series merit careful study because they represent the pooled experience of cardiac catheterization in 363 patients from 57 centres (Tables 3 and 4 ). In the early days of intracardiac investigation it soon became evident that patients with Ebstein's anomaly were high risk cases. Some went so far as to say that if this diagnosis were suspected on clinical grounds, they should not be catheterized (Campbell, 1953; Wood,
1956). However, with the successful application of surgery for so many congenital cardiac malformations, those with Ebstein's anomaly have had to be catheterized like all the others. So long as the risks are appreciated and the procedure is in experienced hands with proper facilities for emergency resuscitation, there is no reason why those with Ebstein's anomaly should not now be investigated in the same way as those with any other serious cardiac lesion for which cardiac surgery is contemplated. The need to appreciate the risk is exemplified by the fact that in this series of 363 cases there were no fewer than 13 deaths and 6 cardiac arrests reported from 16 of the 57 centres performing cardiac catheterization and angiocardiography.

The age and cardiac grade of those who died or were successfully resuscitated after circulatory arrest are shown in Table 3. Of the 6 who survived, 3 had asystolic arrest and 3 had rapid ventricular dysrhythmias; of the 13 who died, 4 had asystolic arrest, 6 had rapid ventricular dysrhythmias, and 3 had very rapid supraventricular tachycardia that could not be controlled and caused acute heart failure. All 19 were in sinus rhythm at the start of the procedure. Only 2 had ventricular preexcitation, an incidence of approximately ro per cent, which is about the same as the incidence of pre-excitation for the whole series of 505 cases. Only 5 had a history of paroxysmal dysrhythmia, i.e. 26 per cent, which is similar to the incidence of 25 per cent (92 patients) in the 363 who were catheterized and of 28 per cent (I43 patients) in the series as a whole. The only clue that might lead one to anticipate trouble during cardiac catheterization is a large heart. Heart size is difficult to quantitate in many cases of Ebstein's anomaly because the heart is not only large but often oddly shaped. It projects on both sides of the mid-line and frequently into the upper hemithorax making it difficult to apply the usual index measurements. With a simple and somewhat impressionistic 3-grade classifica-

TABLE 3 Actual and potential fatality during 363 cardiac catheterizations

19 patients from 16 of 57 centres

\begin{tabular}{|c|c|c|c|c|c|c|}
\hline $\begin{array}{r}13 \text { Deaths } \\
2 \text { days (IV) } \\
2 \text { (III) } \\
\text { Io (III) }\end{array}$ & $\begin{array}{r}19 \text { days (IV) } \\
2 \text { (IV) } \\
22 \text { (III) }\end{array}$ & $\begin{array}{c}24 \text { days (IV) } \\
3 \text { (III) } \\
23 \text { (I) }\end{array}$ & $\begin{array}{r}\text { I month (II) } \\
4 \text { (II) }\end{array}$ & & $\begin{array}{r}2 \text { months (III) } \\
9 \text { (IV) }\end{array}$ & $=3.6 \%$ \\
\hline \multirow[t]{2}{*}{$\begin{array}{c}6 \text { Cardiac arrests } \\
2 \text { (IV) } \\
18 \text { (III) }\end{array}$} & 9 (II) & I2 (I) & I4 (I) & 16 & (III) & $=\mathrm{I} \cdot 7 \%$ \\
\hline & & & & & Total I9 & $=5.3 \%$ \\
\hline
\end{tabular}

* Age in years, except where otherwise stated. Cardiac grade in brackets. 
TABLE 4 Dysrhythmias during 363 cardiac catheterizations

\begin{tabular}{lr}
\hline Dysrhythmia & No. \\
\hline Atrial tachycardia & 46 \\
Atrial fibrillation & 8 \\
Atrial flutter & 3 \\
Multiple supraventricular & 7 \\
Supraventricular and ventricular & 16 \\
Ventricular tachycardia & 5 \\
Ventricular fibrillation & 5 \\
Bradycardia & 3 \\
AV block & 3 \\
Other & 4 \\
\hline & Total \\
\hline
\end{tabular}

tion of heart size, it was found that those who could not be resuscitated were much more likely to have gross cardiomegaly than those who survived; in this way they resembled those who died natural deaths from heart failure. Those who died sudden natural deaths usually had smaller hearts. Exceptions were, however, common; 3 of the 13 who did not survive cardiac catheterization had relatively small hearts and 2 of the 6 who were successfully resuscitated had gross cardiomegaly.

Paroxysmal dysrhythmia was reported in no less than 100 of the 363 patients undergoing cardiac catheterization. The details are shown in Table 4. Opinion, of course, varies between one clinic and another about what constitutes more than the normal rhythm disturbances that might be expected during intracardiac manipulations, but by any standard this is a formidable list. Mostly supraventricular, they were often extremely rapid and sometimes very difficult to stop. Therefore, whatever else one must be prepared to deal with during the intracardiac investigation of patients with Ebstein's anomaly, all manner of dysrhythmias must be expected, any one of which might be life-threatening. Many paroxysms were short-lived and self-terminating. Many could be stopped by simple physical means such as stimulating the heart with the point or a loop of the catheter, and others responded to vagal stimulation or drugs used during the procedure. It is clear, however, that patients should not be returned to the ward with persisting tachycardia in the hope that drugs will, through time, be effective in its control. There are many reports of a rapid downhill course in such circumstances that sometimes becomes irreversible. Paroxysms that cannot be stopped by simple physical or pharmacological means in the theatre should be treated electrically by DC shock, which now seems the most effective way to prevent a serious outcome.

\section{Deaths from natural causes}

The deaths from natural causes are summarized in Table 5. After an initially high mortality from congestive heart failure during the first few months of life, the mortality settles to an average of 12.4 per cent, which is scattered fairly uniformly throughout childhood and adolescence (Fig.). The figures for the first year of life, though instructive, are misleading. Congestive heart failure, ill-advised operations, and cardiac catheterization took a heavy toll, and only 2 of the 30 under 6 months of age survived. These figures grossly overestimate the severity of the lesion in infancy. The fact that only 25 of the 62 centres contributing to the series had seen patients under I year of age, confirms that the malformation is often overlooked in babies, almost certainly

TABLE 5 Number and nature of natural deaths in various age groups: 77 of the 505 patients (15.2\%) died natural deaths

Under I year

16 deaths in 35 patients $=45.7 \%$

I5 (94\%) due to $\mathrm{CHF}=42.9 \%$

(all under 6 months)

I $(6 \%)$ sudden death $=2 \cdot 8 \%$

(Io months)

16 in 26 patients

(8 in 9 patients
$62 \%$
$89 \%)+$

$$
\begin{aligned}
& \text { Between I and } 25 \text { years } \\
& 50 \text { deaths in } 403 \text { patients }=12.4 \% \\
& 25(50 \%) \text { due to CHF }=6.2 \% \\
& \text { ( } 9 \text { III: I3 IV) } \\
& \text { 10 (20\%) sudden death }=2.5 \% \\
& \text { (6 II: } 4 \text { III) } \\
& 9 \text { other deaths from known causes } \\
& 6 \text { deaths from unknown causes }
\end{aligned}
$$

Total natural deaths in non-surgical patients *

50 in 346 patients

$(32$ in 57 patients

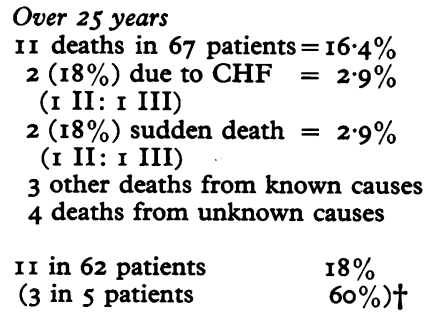

Over 25 years

II deaths in 67 patients $=16.4 \%$

$2(18 \%)$ due to $\mathrm{CHF}=2.9 \%$

(I II: I III)

$2(18 \%)$ sudden death $=2.9 \%$

(I II: I III)

3 other deaths from known causes

4 deaths from unknown causes

$I I$ in 62 patients

( 3 in 5 patients

$\mathrm{CHF}=$ congestive heart failure.

Cardiac grade in brackets.

* Excludes catheter deaths.

† Surgical mortality in brackets for comparison. 
because in most cases it causes so little trouble. Corroborative evidence for this belief is found in the 465 answers on the questionnaire about growth and development during infancy, which was said to be good in 106, average in 243 , and poor in only II6. If a correct diagnosis is made, most of those who are in trouble early in life can be tided over the first few months with intensive medical treatment, after which their prognosis rapidly improves. Special care must be taken with intracardiac investigation in neonates. Surgery appears to have nothing to offer and is almost certainly contraindicated at this age.

Between the ages of I and 25 years, 50 of the 403 patients died from natural causes. Half of the deaths were due to congestive failure and one-fifth of them were sudden deaths, presumably due to disturbances of rhythm. As might be expected the great majority of those who died in failure had previously been in a poor cardiac grade; 88 per cent were in grades III or IV, and all but one of these had very large hearts. Of those who died suddenly, on the other hand, the majority could also be classified as unexpected deaths because 60 per cent were in grade II and half had only moderate cardiac enlargement. The mortality rate for the 346 in this age group who did not have surgical treatment was 15 per cent, which compares very favourably with a surgical mortality of 56 per cent in the 57 patients who had cardiac surgery.

TABLE 6 Natural deaths in age group I to 15 years

$$
\begin{aligned}
& 35 \text { deaths in } 279 \text { patients }=12.5 \% \\
& \text { 19 ( } 54 \% \text { ) due to CHF }=6.8 \% \\
& (4 \text { III: 12 IV) } \\
& 6 \text { (I7 } \% \text { ) sudden death }=2.2 \% \\
& (3 \mathrm{II}: 3 \text { III) } \\
& 4 \text { deaths from acute infections } \\
& 6 \text { deaths from unknown causes }
\end{aligned}
$$

This represents a mortality rate of 14.8 per cent in the 237 who had no surgery compared with a mortality rate of 64.3 per cent in the 42 who had surgery.
The experience of the 67 patients over 25 years of age is not greatly different. The oldest patient to die was $6 I$, and the II natural deaths give a mortality of 16.4 or 18 per cent of the 62 who did not have surgical treatment. Again the surgical mortality was high, with 3 of the 5 failing to survive operation. The numbers in this age group are smaller, but heart failure and sudden death claimed an equal number of victims, continuing the trend towards sudden death rather than congestive failure with increasing age. These older patients also tended to have larger hearts.

Two common causes of death were heart failure after prolonged tachycardia in 4 cases whose ages and cardiac grade were 5 (III), 22 (III), 23 (II), and 30 years (III), and heart failure during acute infections in 8 cases aged I (III), 3 (I), 6 (II), 13 (III), I5 (III), I8 (III), 2 I (III) and 38 (II), 4 of them pneumonia. In Io cases, aged 9 (III), I2 (III), 13 (III), I5 (III), I8 (III), 24 (III), 27 (III), 29 (II), 43 (IV), and 44 years (II), the cause of death was not known. With a few exceptions these deaths also occurred in patients who were considerably disabled and had gross cardiomegaly.

When those in the arbitrarily determined group between I and 15 years are considered separately (Table 6), they show little difference so far as natural deaths are concerned from the larger group aged I to 25 years. Of the 19 who died of heart failure, I6 were in cardiac grades III or IV and 17 had large hearts. Of the 6 who died suddenly, 4 had only modest cardiac enlargement and 3 had little handicap, though, as in the larger group, the correlation between heart size and handicap was not good. The surgical experience in this younger group, however, was even worse than in older patients; 64.3 per cent of the 42 who had surgery did not survive it.

\section{Surgical experience}

Surgical treatment was reported by 30 of the 61 contributors in 17 countries, much of it carried out at leading world centres: 9 had experience of only

\section{TABLE 7 Surgical experience in 505 cases ${ }^{\star}$}

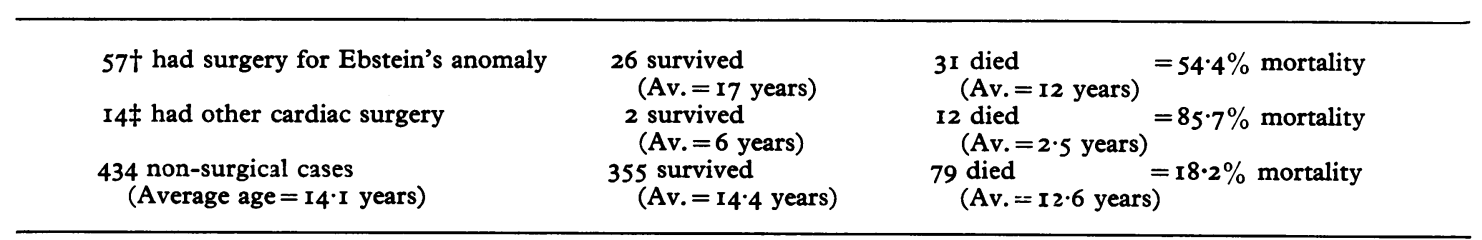

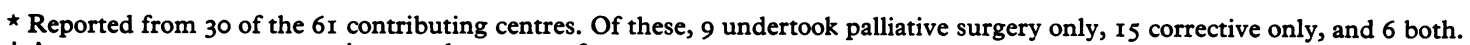
$\dagger$ Average age 14 years. 4 patients under I year of age.

$¥ 9$ were I year old or less. 
palliative operations, 15 of only corrective operations, and 6 of both; 71 of the 505 patients in the series had operations on their hearts. The overall results are shown in Table 7, where the outcome in the 434 patients who did not have surgery is also given for comparison. More than half of the 57 who had surgical treatment for Ebstein's anomaly did not survive, and only 2 of 14 survived other heart surgery, by which is meant treatment for an associated cardiac malformation or thoracotomy after an incorrrect diagnosis.

Palliative procedures appear to have nothing to offer. In the young they carry a prohibitive mortality with little hope of anything but modest improvement (Table 8). Of the 17 patients under 15 years of age submitted to this form of surgical treatment. I I $(64 \%)$ did not survive; 5 of them were in cardiac grades I or II at the time, as were all 6 who survived. In those over I 5 the results were no better (Table 9), with 3 deaths in 5 cases.

The tricuspid valve was replaced in 31 patients (27 with Starr Edwards or other prostheses and 4 with homografts); 16 were under I5 years of age and 15 were over 15 years of age. The results in the younger patients are shown in Table Io. Only 7 of the 16 survived, a mortality of 56 per cent; 4 of the 9 surgical deaths were in cardiac grade II. The chance of survival for those of 12 and under was much less than for the group as a whole; only 4 of these 12 patients survived, a mortality of 67 per cent. Table Io also indicates an all or none response to definitive

TABLE 8 Results of pallative surgical treatment in I7 patients between I and I5 years of age

\begin{tabular}{|c|c|c|c|}
\hline $\begin{array}{l}\text { Age } \\
(y r)\end{array}$ & $\begin{array}{l}\text { Cardiac } \\
\text { grade }\end{array}$ & Operation & Result \\
\hline I & III & Glenn & Surgical death \\
\hline 5 & III & Glenn & Surgical death \\
\hline 7 & II & Blalock & Surgical death \\
\hline 8 & III & Glenn & $\begin{array}{l}\text { Died, acute postop. heart } \\
\text { failure }\end{array}$ \\
\hline 10 & II & Glenn & $\begin{array}{l}\text { Died, acute postop. heart } \\
\text { failure }\end{array}$ \\
\hline 10 & II & ASD closed & $\begin{array}{l}\text { Died, acute postop. heart } \\
\text { failure }\end{array}$ \\
\hline II & II & Blalock & Surgical death \\
\hline II & III & Glenn & Surgical death \\
\hline 12 & III & Glenn & $\begin{array}{l}\text { Died, acute postop. heart } \\
\text { failure }\end{array}$ \\
\hline I4 & I & Blalock & Died, postop. sepsis \\
\hline 14 & III & Blalock & Surgical death \\
\hline 5 & I & Blalock & Moderately improved \\
\hline 8 & II & Glenn & Moderately improved \\
\hline IO & II & Blalock & Slightly improved \\
\hline II & II & Glenn & Moderately improved \\
\hline I I & I & Plication & Satisfactory \\
\hline 13 & II & Glenn & Not improved \\
\hline
\end{tabular}

TABLE 9 Results of palliative surgical treatment in 5 patients over 15 years of age

\begin{tabular}{|c|c|c|c|}
\hline $\begin{array}{l}\text { Age } \\
(y r)\end{array}$ & $\begin{array}{l}\text { Cardiac } \\
\text { grade }\end{array}$ & Operation & Result \\
\hline 20 & III & ASD closed & Surgical death \\
\hline 30 & III & Blalock & Surgical death \\
\hline 31 & III & ASD closed & $\begin{array}{l}\text { Died, acute postop. heart } \\
\text { failure }\end{array}$ \\
\hline 20 & I & Glenn & Slightly improved \\
\hline 34 & IV & Plication & Improved \\
\hline
\end{tabular}

TABLE IO Results of definitive surgical treatment in I6 patients between $I$ and 15 years of age

\begin{tabular}{|c|c|c|c|}
\hline $\begin{array}{l}\text { Age } \\
(y r)\end{array}$ & $\begin{array}{l}\text { Cardiac } \\
\text { grade }\end{array}$ & Operation & Result \\
\hline 3 & III & Prosthesis & Surgical death \\
\hline 4 & II & Prosthesis & Surgical death \\
\hline 5 & II & Prosthesis & $\begin{array}{l}\text { Died, acute postop. heart } \\
\text { failure }\end{array}$ \\
\hline 6 & IV & Prosthesis & Surgical death \\
\hline 9 & II & $\begin{array}{c}\text { Prosthesis } \\
\text { + ASD } \\
\text { closed }\end{array}$ & $\begin{array}{l}\text { Died, acute postop. heart } \\
\text { failure }\end{array}$ \\
\hline 9 & III & Prosthesis & $\begin{array}{l}\text { Died, acute postop. heart } \\
\text { failure }\end{array}$ \\
\hline II & III & $\begin{array}{c}\text { Prosthesis } \\
\text { + ASD } \\
\text { closed }\end{array}$ & $\begin{array}{l}\text { Died, acute postop. heart } \\
\text { failure }\end{array}$ \\
\hline 12 & II & Prosthesis & Died, postop. sepsis \\
\hline 13 & IV & Prosthesis & Surgical death \\
\hline 6 & II & Prosthesis & Greatly improved \\
\hline 7 & II & Homograft & Greatly improved \\
\hline 10 & II & Prosthesis & Greatly improved \\
\hline II & II & Prosthesis & Greatly improved \\
\hline I4 & II & Prosthesis & Greatly improved \\
\hline I5 & II & Prosthesis & Slightly improved \\
\hline 15 & III & Homograft & Greatly improved \\
\hline
\end{tabular}

surgical treatment. With one exception the patients were either greatly improved by the operation or failed to survive it.

The experience with tricuspid valve replacement in patients over 15 years of age is shown in Table II. Much better results were obtained in these 15 larger patients, Io of whom survived, a mortality of 33 per cent; all 5 who died were in cardiac grades III or IV. Again, with only one exception, the patients, whose cardiac grades before operation were by and large poorer than those in the younger group, were either greatly improved after the insertion of a prosthesis or did not survive the attempt to insert it.

The total surgical experience (palliative and definite) and a comparison between the surgical mortality and death from natural causes are summarized in Table 12. In the younger group those who had surgical treatment were on average a little 
TABLE I I Results of definitive surgical treatment in I5 patients over 15 years of age

\begin{tabular}{|c|c|c|c|}
\hline $\begin{array}{l}\text { Age } \\
(y r)\end{array}$ & $\begin{array}{l}\text { Cardiac } \\
\text { grade }\end{array}$ & Operation & Result \\
\hline 19 & IV & Prosthesis & Surgical death \\
\hline 22 & III & $\begin{array}{l}\text { Prosthesis } \\
\text { + ASD } \\
\text { closed }\end{array}$ & Surgical death \\
\hline 23 & IV & $\begin{array}{l}\text { Prosthesis } \\
\text { + ASD } \\
\text { closed }\end{array}$ & $\begin{array}{l}\text { Died, acute postop. heart } \\
\text { failure }\end{array}$ \\
\hline 23 & IV & Prosthesis & Surgical death \\
\hline 29 & III & Prosthesis & $\begin{array}{l}\text { Died, acute postop. heart } \\
\text { failure }\end{array}$ \\
\hline 16 & III & Prosthesis & Greatly improved \\
\hline 16 & III & Prosthesis & Greatly improved \\
\hline 18 & II & Prosthesis & Greatly improved \\
\hline 19 & II & Prosthesis & Satisfactory \\
\hline 21 & II & Prosthesis & $\begin{array}{l}\text { Satisfactory, but has heart } \\
\text { block }\end{array}$ \\
\hline 21 & IV & Prosthesis & Greatly improved \\
\hline 22 & III & Prosthesis & Greatly improved \\
\hline 24 & III & Homograft & Greatly improved \\
\hline 25 & III & $\begin{array}{c}\text { Prosthesis } \\
\text { + ASD } \\
\text { closed }\end{array}$ & Not improved \\
\hline 43 & III & Homograft & Greatly improved \\
\hline
\end{tabular}

older than those who did not, but there is no difference in the average age of those who died. Though deaths from natural causes remain remarkably constant over the years, the surgical mortality in those over I 5 years of age is much less than in those under I5 years of age. This difference is even more pronounced if the arbitrary division is made at ${ }_{13}$ years and those having palliative procedures are excluded. The surgical mortality is then halved, being 66 per cent in the younger and 32 per cent in the older group having valve replacement.

\section{Discussion}

International co-operation in research may be useful in two situations: one, where it is necessary to compare and contrast experience in different parts of the world; the other, where because of a condition's rarity the net must be cast widely to obtain sufficient material for meaningful analysis. Ebstein's anomaly of the tricuspid valve is a good example of the latter. First described in 1866, it remained a pathological curiosity until the first case diagnosed during life was described by Tourniaire, Deyrieux, and Tartulier in 1949. Until then only 26 specimens had been reported, but since then most clinics have become familiar with the clinical features of what remains one of the rarer congenital cardiac malformations. The wide scatter in the number of cases contributed from centres of comparable size, however, suggests that in many cases the anomaly is still unsuspected. Not unnaturally, it has continued to arouse interest. The published cases have been reviewed many times, usually with the addition of new cases whose numbers have tended to increase from single to double figures over the years. Among recent reports, which contain most of the references, are those by Vacca et al. (1958), Schiebler et al (1959), Genton and Blount (1967), Lowe and Watson (I968), Soulié et al. (I970), Kumar et al. (I97I), Simcha and BonhamCarter (197I), and Bialostozky, Horwitz, and EspinoVela (1972). This study was started in 1968 because no clear picture of the natural history in childhood and adolescence had emerged from the published reports, at a time when surgery was being advocated with increasing frequency before any surgical criteria had been established. It has provided much new factual information about a large number of cases, which has confirmed some features suggested by smaller series and refuted others. It has also provided unequivocal evidence about the role of surgical treatment in the management of those born with this lesion.

Perhaps the most striking thing to emerge from the analysis is the large number of patients with Ebstein's anomaly who are in cardiac grades I or II.

TABLE I2 A summary and comparison of the surgical mortality and death from natural causes

\begin{tabular}{|c|c|c|c|}
\hline \multicolumn{4}{|l|}{279 cases between I and I5 years } \\
\hline $\begin{array}{l}33 \text { had surgery for Ebstein } \\
\text { (Av. } 9 \cdot 2 \text { years) }\end{array}$ & $\begin{array}{l}\text { 13 survived } \\
\text { (Av. } 10.5 \text { years) }\end{array}$ & $\begin{array}{l}20 \text { died } \\
\text { (Av. } 8.8 \text { years) }\end{array}$ & \\
\hline $\begin{array}{l}9 \text { had other surgery } \\
\text { (Av. } 5 \text { years) }\end{array}$ & $\begin{array}{l}2 \text { survived } \\
\text { (Av. 6.0 years) }\end{array}$ & 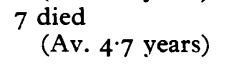 & $=78 \%$ mortality \\
\hline $\begin{array}{l}237 \text { had no surgery } \\
\text { (Av. } 7 \cdot 2 \text { years) }\end{array}$ & $\begin{array}{l}202 \text { survived } \\
(\text { Av. } 7 \cdot 0 \text { years })\end{array}$ & $\begin{array}{l}35 \text { died } \\
\text { (Av. } 8.4 \text { years) }\end{array}$ & $=14.9 \%$ mortality \\
\hline \multicolumn{4}{|l|}{191 cases over I 5 years } \\
\hline $\begin{array}{l}20 \text { had surgery for Ebstein } \\
\text { (Av. 24.I years) }\end{array}$ & $\begin{array}{l}\text { I2 survived } \\
\text { (Av. } 23.8 \text { years) }\end{array}$ & $\begin{array}{l}8 \text { died } \\
(\text { Av. } 24 \cdot 6 \text { years })\end{array}$ & $=40 \%$ mortality \\
\hline $\begin{array}{l}\text { I7I had no surgery } \\
\text { (Av. } 25.6 \text { years) }\end{array}$ & $\begin{array}{l}\text { I45 survived } \\
\text { (Av. } 25.5 \text { years) }\end{array}$ & $\begin{array}{l}26 \text { died } \\
\text { (Av. 26.4 years) }\end{array}$ & $=15.2 \%$ mortality \\
\hline
\end{tabular}


If the first few months of life are excluded, and there is good evidence that only a relatively small number (those who are in trouble) are seen at this age, no less than 73 per cent of those between $I$ and 15 years, 69 per cent of those between 16 and 25 years, and 59 per cent of those over 25 years have been so classified as having no great disability.

This knowledge suggests that one should look fairly critically at the need for surgery in childhood and at what is likely to be achieved by it. Patients with Ebstein's anomaly are bad surgical risks. Operation cannot be advised in the hope that if they are no better, at least they will be no worse after they have recovered from thoracotomy, because the chances are that under these circumstances they will not survive it. Palliative operations are not helpful, and upon reflection, with a better understanding of the haemodynamic upset caused by the malformation, it seems unlikely that much improvement could be expected. As such operations also carry a high mortality it seems fair to conclude that they have no place in treatment and are probably contraindicated. A new tricuspid valve is required, but this is not so easily accomplished where the AV ring is wide and malformed. When an attempt is made to insert a prosthesis, ideally it should be with one that is large enough for adult life; replacing one that is malfunctioning is sufficiently daunting without inviting the prospect of replacing one that has become too small. Deaths reported during the insertion of a prosthesis into 4- and 5-year-old children in cardiac grade II emphasize that attempts should not be made to replace the tricuspid valve merely because it is malformed. The experience of definitive surgery in this series clearly indicates that patients are likely either to be greatly improved by the operation or fail to survive it, and that their chances of surviving it increase as they get older and larger.

So many patients remain in grades I or II throughout childhood and adolescence (and even beyond it), and the number of deaths from natural causes compares so favourably with the surgical mortality, that one wonders if surgery is indicated in such patients whatever their age. It must be remembered, too, that if their grade remains good while they get older, the trend is towards sudden death rather than death from heart failure. So far there is no evidence that successful valve replacement in any way diminishes the risk of sudden death, and it may well be that operation should be delayed and advised only when increasing disability makes it difficult to pursue normal activities.

In case the bias was against the surgically treated group of paediatric age because it contained more patients who were in poorer cardiac grades than the non-treated group, all those between I and 15 years of age have been placed for comparison in 4 groups to show the chance of natural or surgical death according to cardiac grade (Table 13). Taking grades I and II together, only 8 of the I77 patients in the non-surgical group died from natural causes, whereas 13 of the 25 in the surgically treated group died after operations of one sort or another. Taking grades III and IV together, 33 of 60 survived without surgical treatment and only 3 of 17 survived with surgical treatment. Put another way, it can be seen from this Table that for those with little or no disability the odds of 22 to I against death from natural causes are reduced to less than evens by surgical treatment. Even for those who are grossly disabled, surgery in childhood reduced the chances of survival from slightly better than evens to more than 5 to I against.

An attempt was made to discover if the presence of coexisting congenital cardiac malformations influenced the outcome of surgical treatment: 62 per cent of those operated upon were said to have interatrial defects of one sort or another, which is similar to the 60 per cent in the necropsy group. If we exclude such defects from the discussion, 29 per cent of those who failed to survive operations had other cardiac lesions compared with 12 per cent in the catheter series of 363 cases and 42 per cent in the necropsy series of 93 cases. Many cases are, of course, common to all three groups, but any attempt

TABLE I3 Cardiac grades of natural and surgical deaths in age groups I to I5 years with chance of survival

\begin{tabular}{|c|c|c|c|c|}
\hline Cardiac grade & $I$ & $I I$ & $I I I$ & $I V$ \\
\hline $\begin{array}{l}279 \text { cases } \\
237 \text { non-surgical cases } \\
35 \text { natural deaths } \\
\text { Chance of natural death } \\
42 \text { surgical cases } \\
27 \text { surgical deaths } \\
\text { Chance of surgical death }\end{array}$ & $\begin{array}{l}72(26 \%) \\
68(29 \%) \\
\text { I }(3 \%) \\
I \cdot 5 \% \\
4(9 \%) \\
I(4 \%) \\
25 \%\end{array}$ & $\begin{array}{l}\text { I30 }(47 \%) \\
\text { I09 }(46 \%) \\
7(20 \%) \\
6.4 \% \\
21(50 \%) \\
12(44 \%) \\
57 \%\end{array}$ & $\begin{array}{l}52(18 \%) \\
40(17 \%) \\
15(43 \%) \\
37.5 \% \\
12(29 \%) \\
10(37 \%) \\
83 \%\end{array}$ & $\begin{array}{l}25(9 \%) \\
20(8 \%) \\
12(34 \%) \\
60 \% \\
5(12 \%) \\
4(15 \%) \\
80 \%\end{array}$ \\
\hline
\end{tabular}


to separate them leaves numbers that are too small for analysis. The overall surgical mortality was certainly higher in the 15 patients who had associated cardiac malformations, 73 per cent compared with 5I per cent in those who were said either to have none or only to have defects in the interatrial septum. This figure is perhaps unduly influenced by the fact that all 4 of those with associated malformations in whom a prosthesis was inserted, failed to survive the operation. The difference between the two groups was otherwise around Io per cent. When 52 of the 6r who died natural deaths and who had catheter or necropsy proof of diagnosis were similarly analysed, 62 per cent, or 21 per cent if defects in the interatrial septum are excluded, were found to have associated congenital cardiac malformations. These figures are significantly higher than 48 per cent and 12 per cent, in the 363 patients who were catheterized, but very much lower than those reported by Kumar et al. (1971) from Boston. Here 18 of 40 patients having catheter or necropsy proof of diagnosis had associated cardiac anomalies other than those involving the interatrial septum. This figure of 45 per cent, and the fact that 40 per cent of the patients were seen before 6 months and 60 per cent before 2 years of age, suggests that they were dealing with a group of 55 much more serious cases and probably explains why their prognosis was so poor; only 50 per cent survived up to 13 years of age. If one takes a similar age group out of this series of 505 patients heavily weighted with those in the first 2 years of life, the prognosis is even worse; only 21 of 63 patients under 2 survived. This suggests that as for other congenital cardiac malformations, so for Ebstein's anomaly, one specialized clinic's experience is not necessarily typical of all hospital experience and rarely reflects prevalence in the community. The present series, of course, is equally open to criticism, containing as it does a large number of cases collected at random from all parts of the world. Some contributions represent a fair cross-section of local experience, others the occasional chance diagnosis. Neither reflects true prevalence, which probably lies somewhere between them.

An attempt has also been made to correlate the radiological and electrocardiographic features, which will be published later, with mortality. Though the data are not yet complete, it is already obvious that the reported incidence of pre-excitation and paroxysmal dysrhythmia is no greater in those who died, even in the sudden deaths, than in the series as a whole. Patients dying suddenly under 15 years of age tended to have smaller hearts than those who died in heart failure, and larger hearts than those who survived. In those over 15, the hearts of both those dying suddenly and in heart failure were larger than in the younger patients and the difference between the two all but disappeared, though both had larger hearts than the majority of those who survived. There are, however, so many exceptions that heart size is not helpful in predicting the outcome for individual cases, especially as they get older. While gross cardiomegaly is an unfavourable sign, large numbers of patients survive for many years with hearts that practically fill the thorax.

\section{Appendix}

\section{List of contributors}

J. Bartel, Berlin, D.D.R.; A. Blancquaert, Gent, Belgium; I. Boesen, A. Wennevold, and J. Fischer Hansen, Copenhagen, Denmark; K. K. Bossina, Groningen, The Netherlands; K. Buhlmeyer, Munich, W. Germany; H J. Busch, Nijmegen, The Netherlands; L-E. Carlgren, Gothenberg, Sweden; G. Cherian, K. I. Vytilingan, and S. C. Munsi, Vellore, India; A. Chroscicki, Warsaw, Poland; E. Coelho, Lisbon, Portugal; M. Dahl, Turko, Finland; V. H. de Villeneuve, Rotterdam, The Netherlands; K. Dymnicka, Gdansk, Poland; J. EspinoVela, Mexico City, Mexico; D. Fettich, Ljubljana, Yugoslavia; R. Fono, Budapest, Hungary; E. Freixa-Taxonera, Barcelona, Spain; A. Gallez, Brussels, Belgium; M. Gautier, Paris, France; R. Gerard, Marseilles, France; J. F. Goodwin and K. A. Hallidie-Smith, London, England; B. Guller, Lausanne, Switzerland; H. Gutheil, Erlangen, W. Germany; J. D. Hay, and J. Shackleton, Liverpool, England; I. Jakubcova, Bratislava, Czechoslovakia; H. C. Kallfelz, Bonn, W. Germany; J. Kamaras, Budapest, Hungary; E. W. Keck and W. G. Henschel, Hamburg, W. Germany; J. D. Keith and P. M. Olley, Toronto, Canada; E. C. Lambert, Buffalo, U..S.A.; G. Losekoot, Amsterdam, The Netherlands; D. G. McNamara, Houston, Texas; M. Michaëlsson, Uppsala, Sweden; S. C. Mitchell, Washington, U.S.A.; T. Nagayama, Fukuoka, Japan; H. N. Neufeld and M. Hack, Tel-Aviv, Israel; J. Nihoyannopoulos, Athens, Greece; P. Ninova, Sophia, Bulgaria; A. Olariu-Ungureanu, Bucharest, Rumania; C. G. Parsons and S. P. Singh, Birmingham, England; S. Pelargonio, Rome, Italy; C. Pernot, Nancy, France; W. A. Pocock and J. B. Barlow, Johannesburg, South Africa; P. Puech, Montpellier, France; C. Romano, Genoa, Italy; F. Rovelli and M. Colombi, Milan, Italy; R. D. Rowe, Catherine A. Neill, and F. Chu, Baltimore, U.S.A.; O. Scott, Leeds, England; J. Somerville, London, England; J. T. Widerski, Warsaw, Poland; C. Thoren, Stockholm, Sweden; L. Tuuteri and B. Landtman, Helsinki, Finland; 
L. G. Van Der Hauwaert, Louvain, Belgium; A. W. Venables, Melbourne, Australia; B. Vitek, Brno, Czechoslovakia; A. Vliers, Haverlee, Belgium; $\mathbf{H}$. Watson and K. G. Lowe, Dundee, Scotland; J. W. Weber, Bern, Switzerland; F. Wyler, Basel, Switzerland; E. Zera, Poland; R. Zuckermann and G. Wagner, Halle, D.D.R.

\section{References}

Bialostozky, D., Horwitz, S., and Espino-Vela, J. (1972). Ebstein's malformation of the tricuspid valve. A review of 65 cases. American fournal of Cardiology, 29, 826.

Campbell, M. (1953). Editorial comment on Ebstein's anomaly diagnosed during life, by C. B. Henderson, F. Jackson and W. G. A. Swan. British Heart Fournal, 15, 360.

Ebstein, W. (1866). Utber einen sehr seltenen Fall von Insufficienz der Valvula tricuspidalis, bedingt durch eine angeborene hochgradige Missbildung deselben. Archiv für Anatomie und Physiologie, 33, 238.

Genton, E., and Blount, S. G., Jr. (1967). The spectrum of Ebstein's anomaly. American Heart fournal, 73, 395.

Kumar, A. E., Fyler, D. C., Miettinen, O. S., and Nadas, A. S. (197I). Ebstein's anomaly. Clinical profile and natural history. American fournal of Cardiology, 28, 84 .
Lowe, K. G., and Watson, H. (1968). Ebstein's anomaly of the tricuspid valve. In Paediatric Cardiology, p. 437. Ed. by Hamish Watson. Lloyd-Luke, London.

Schiebler, G. L., Adams, P., Jr., Anderson, R. C., Amplatz, K., and Lester, R. G. (1959). Clinical study of twentythree cases of Ebstein's anomaly of the tricuspid valve. Circulation, 19, 165.

Simcha, A., and Bonham-Carter, R. E. (1971). Ebstein's anomaly. Clinical study of 32 patients in childhood. British Heart fournal, 33, 46.

Soulié, P., Heulin, C., Pauly-Laubry, C., and Degeorges, M. (1970). Maladie d'Ebstein. Etude clinique et evolution (à propos de 40 observations, dont 9 chirurgicales). Archives des Maladies du Coeur et des Vaisseaux, 63, 615.

Tourniaire, M., Deyrieux, F., and Tartulier, M. (1949). Maladie d'Ebstein: essai de diagnostic clinique. Archives des Maladies du Coeur et des Vaisseaux, 42, 1211.

Vacca, J. B., Bussmann, D. W., and Mudd, J. G. (1958). Ebstein's anomaly: complete review of 108 cases. American Fournal of Cardiology, 2, 210.

Wood, P. (1956). Diseases of the Heart and Circulation, 2nd ed. pp. 188 and 356. Eyre and Spottiswoode, London.

Requests for reprints to Dr. Hamish Watson, Department of Cardiology, Ninewells Hospital, Dundee DDI 9ND. 